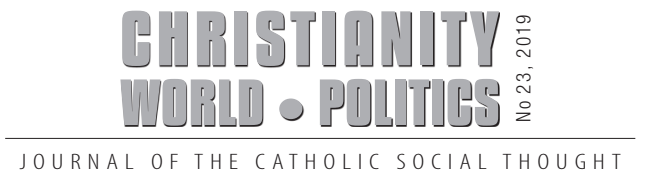

Michał Gierycz

Cardinal Stefan Wyszyński University in Warsaw, Poland

\title{
Overcoming Reductionism. On „In-depth” Systems Analysis in the Political Science of Religion
}

\begin{abstract}
Abstact: The starting point of the article is the observation made by Ernst Wolfgang Böckenförde, according to which political science perceives itself as an ,atheistic science in its proper sense" and documents problematic consequences of this paradigm on the grounds of "political science of religion” (such as, for example, reducing religion to ideology and Churches to groups of interests). In this context the author poses a question whether the theory and the instrumentarium of the political science creates possibilities of non-reduction approach to religion. The article provides an answer to this question. In the first part, outlining changes in the understanding of political science, the author proves that political science, in its theoretical and methodological body leaves some space for what we currently define as "political science of religion”, as well as reveals the sources of special importance of the system paradigm for political research. The second part brings the analysis of the current interpretation of this paradigm and shows their role in consolidating the "religious cataract” of political science. In the third part, referring to Easton's writing, the author presents the theoretical possibilities of "deepening” the system analysis as well as examples of research techniques and approaches, allowing us to analyze the role of religion in political processes in a non-reduction way. The article proves therefore that it is possible to analyze religion as a social phenomenon differring from politics not only from the theoretical, but also from methodologicsl perspective (the so-called in-depth system analysis).
\end{abstract}

Keywords: political science of religion, systems analysis, paradigm, atheism, scientific character

Abstrakt: Punktem wyjścia artykułu jest spostrzeżenie Ernsta Wolfganga Böckenförde, zgodnie z którym nauki polityczne pojmują siebie jako naukę „ateistyczną we właściwym znaczeniu” i dokumentuje problematyczne konsekwencje tego paradygmatu na gruncie „politologii religii” (jak np. redukcję religii do ideologii, a Kościołów do grup interesu). W tym kontekście autor stawia pytanie, czy teoria i instrumentarium nauk o polityce stwarzają możliwości 
nie-redukcyjnego podejścia do religii. Od powiedzi na to pytanie poświęcony jest niniejszy artykuł. W pierwszej części, szkicując przemiany w pojmowaniu politologii, autor dowodzi, że politologia w swym teoretyczno-metodologicznym korpusie zostawia miejsce na coś, co określamy współcześnie mianem „politologii religii”, jak również odsłania źródła szczególnego znaczenia paradygmatu systemowego dla badań politologicznych. W drugiej części rozważone zostały współczesne interpretacje tego paradygmatu i ukazana ich rola w ugruntowywaniu „religijnej katarakty” politologii. W trzeciej, w nawiązaniu do pism Eastona, autor ukazuje teoretyczne możliwości „pogłębienia” analizy systemowej, jak również przykładowe techniki i podejścia badawcze, umożliwiające badania roli religii w procesach politycznych w sposób nieredukcyjny. Artykuł dowodzi zatem, że nie tylko z perspektywy teoretycznej, ale również metodologicznej, możliwe jest badanie religii właśnie jako fenomenu społecznego różnego od polityki (tzw. głęboka analiza systemowa).

Słowa kluczowe: politologia religii, analiza systemowa, paradygmat, ateizm, naukowość

In his well-known article, Ernst Wolfgang Böckenförde points out that even though for thousands of years the thinking and theories of political order in the society were related to religious imagery, and in the times of Christianity - also to theological ones, political science considers itself to be a science that is "atheist in the proper sense of the word" [cf. Boeckenfoerde 2005:301]. This issue becomes particularly significant in the context of the intense development, also in Poland, of the so-called "political science of religion" [cf. Haynes 2009, Marczewska-Rytko 2010, Dylus 2016, Michalak 2016, Burgoński, Gierycz 2014], which studies the relationship between religion and politics from the perspective of political science. When reviewing literature on the subject, one cannot help but notice that most politological analyses have a predominantly descriptive value, while their theoretical value is fairly limited. Moreover, attempts made by political science at explaining the significance of the religious factor leave much to be desired in terms of their merits content-wise. As pointed out by Timothy Longman [2001], they seem to reflect three approaches to religion. Scholars who focus on social conflicts usually see religion as an aspect of identity which defines individual members as part of a social group, and thus acts as an intermediary in their relationships with other social groups and the state. For example, in literature on genocide, religion is treated as a tool used to define members of certain groups as being "the other" in social terms, and thus as a substantiation of their social exclusion. In another popular approach to religion in political science, religious 
groups are seen as interest groups, just like trade unions, women's federations, or non-governmental organizations which bring together like-minded people to consolidate their political power. Longman, however, postulates that the Church should be treated as an inherently political institution. He claims that the classical definition of politics suggested by Harold Lasswell (1936), who describes it as a struggle over "who gets what, when, and how", leads to the conclusion that churches are clearly political institutions, as they play an important role in the distribution of resources. Ultimately, then, theoretical perspectives of viewing the Church and religion in mainstream political science are limited to understanding religious communities as: (1) a source of conflict-generating nationalism; (2) interest groups; and finally as (3) political institutions sensu stricte, with the result of viewing religion as an ideology.

The problem with this approach, represented in many works of political science, is self-evident. It is not a consequence of the fact that these three perspectives are entirely wrong. It is quite obvious that religion plays an important role in building national identities, that religious institutions may operate just like interest groups (see for example the activity of COMECE in Brussels [Gierycz 2008]), or that they may evoke certain political goals [Dylus 2014], and religion may be reduced to the level of ideology [Sulkowski 2018]. The problem, and a serious one at that, of the predominant way of looking at the relationship between religion and politics in political science is its reductionism, i.e. peremptory reduction of religion to ideological and political phenomena. If, however, capturing the Church, for example, precisely as the Church is beyond the cognitive abilities of a political scientist, then consequently the proper understanding of religion, Catholicism and the Church in the area of politics will be just as much beyond his cognitive abilities as well. We may add that this type of an essentially atheistic approach ultimately leads to annihilation of the object of study. If, as suggested by Longman, we consider religious communities as "inherently political institutions", we are in fact removing any distinction between religion and politics, consequently doing away also with the point of examining the particular contribution made by religion to political processes.

In this context, we must ask whether the theory and the inventory of political science allow for taking any approach to religion which is not a priori reductionist in nature. What I mean is an approach which recognizes that religion as a phenomenon based on the relationship between man and a transcendent reality (the Absolute, sacrum) is not an "add-on" to man's life, but is that which determines his individual identity (and group identities as well) at its 
very foundations, and may not be reduced to mere "opinions"; that religion as a doctrine referring to eschatological issues and placing its greatest hopes there is clearly not the same as ideology, whose goals belong to the temporal order; and, finally, that religion as the foundation of a community (religious organization) has a place in the public sphere that is not reducible to that of any other bodies or NGOs. In short, in this article I would like first of all to look into the possibility of viewing the phenomenon of religion in political studies in the entirety of its otherness from all that political science has become used to and has learned to study. Only if this "otherness" is recognized of the phenomenon of religion, and its political meaning is acknowledged precisely due to this otherness, can any new contribution be made to political studies by the political science of religion.

In view of the above research objective, this article has been divided into three parts. In the first part, by briefly outlining developments in the understanding of political science I argue that in its main theoretical and methodological body political science leaves room for what is today called a "political science of religion". I also reveal sources of the special significance of the systems paradigm for political studies. In the second part, I consider some contemporary interpretations of this paradigm, presenting their role in consolidating the "religious cataract" of political science. In the third part, referring to the work of Easton, I present some theoretical possibilities of adding depth to systems analysis, and discuss sample research techniques and approaches which support a non-reductive study of the meaning of religion for politics within the systems paradigm. This allows me to demonstrate that not only from the theoretical, but also from the methodological perspective it is possible to study religion as a social phenomenon that is "different" from politics (in the so-called on-depth systems analysis).

There are two reservations that needs to be made here. First, the problem I have set out to analyze can only be taken up if we assume that the understanding of scientificity prevailing at the turn of the $19^{\text {th }}$ and $20^{\text {th }}$ century, which claimed that political and social sciences should only rely on rational, empirically verifiable statements, and on this basis study and explain social phenomena and manifestations of order [cf. Boeckenfoerde 2005:301-302], is a historical one. And consequently that, just like due to its genesis political science put the question of God "in parentheses", becoming an "atheist science in the proper sense of the word", so it may, in the course of its development, take the question of God "out of parentheses". Ultimately, even remaining on the grounds of scientific achievements (in 
the sense of natural sciences), it must be admitted that "the issue of God remains an open question".

Secondly, even though in the title I refer to religion as such, and generally the comments below are universally applicable, in a more detailed way my reflections should be read from the perspective of religions characteristic for the Western hemisphere, which means broadly understood Christianity. Even though there are many issues over which various Christian denominations are divided, they have much more in common, particularly compared to other great religious traditions, such as Islam or Buddhism. One of the specifically Christian elements of key importance for my reflections here is the assumed autonomy of "temporal realities" (nonexistent for example in Islam), which has allowed for the development in Europe of an understanding of politics and science which is characteristic for the Old Continent. Consequently, my assertions presented here should be treated as middle-range claims, which would need to be adequately adapted if they were to be referred to other great religious traditions.

\section{Methodological currents in political studies and the possibility of a „political science of religion"}

As pointed out by Andrzej Antoszewski, political science „has not developed its own proper research method" [Antoszewski 2004:328]. On the contrary, it features a "pluralism of the objects of study, methods and techniques of research" [Woleński 1974:34]. It does not mean a methodological chaos, however. Its methods form clearly identifiable groups, developing in each subsequent period of the history of political science. For the sake of order in our narration, let us briefly take a look at the main methodological currents from the theoretical and historical perspective.

Political science, developing in the context of science of the state, initially remained under the influence of the normative and institutional approach, as well as the historical perspective. „The historical emphasis produced detailed descriptions of the developments leading to political events and practices. Legalism, in contrast, involved the study of constitutions and legal codes. And the concentration on institutions included studies of the powers and functions of political institutions such as legislatures, bureaucracies, and courts" [Johnson, Reynolds, Mycoff 2012:62]. Consequently, traditional political science was focused on formal governments and their legally defined powers, and - as claimed by its critics - not only failed to take into account informal political 
processes, but was essentially descriptive. In addition to the above initial features of political science, it remained a normatively-oriented one. If - as was claimed by Christian Schwaabe - Aristotle should be considered the author of political science [Schwaabe 2010], it becomes apparent that at the outset it developed normative theories regarding the essence of politics and the goals and optimum form of government.

Does political science understood this way have any specific research instruments at its disposal? As has been euphemistically remarked by Marek Sobolewski, as regards the relationship between political science and history, attempts made by political scientists at using a different workshop to write about history have had "very mixed results" [Sobolewski 1975:242]. If we look for a contribution made by political science to the study of recent history, and to the history of ideas, we will not find it essentially in the field of developing its own instruments, but rather in pointing to issues which had been marginalized in traditional historiography. They include for example "study of the social make-up of representative bodies, particularly the parliament, study of the content of magazines and the political role played by newspapers, study of the development of the organizations of "interest", and study of the genesis of political parties" [Sobolewski 1975:243]. When studying the genesis of political institutions or ideologies, or when looking for an empirical basis for the generalization and verification of scientific laws, political science is "doomed" to methods and techniques typical of historical sciences. An analogous situation occurs in the relationship between political science and legal science and philosophy. Normative analysis, exegesis, and hermeneutic tools are now adapted to political science from the inventory employed in the latter sciences.

The traditional approach to political studies has been increasingly challenged since the 1950s. The main charge against them was the lack of any empirical verification of "verbal theories", which - particularly in view of the development of sociology and cultural anthropology - resulted in a sense of political science being "methodologically backward". In the United States at the beginning of the 1960s, the so-called "behavioral revolution" began, consisting - to put it briefly in "shifting the emphasis from how political phenomena, processes, or activities should proceed, to the actual course of political phenomena and processes and the actual behavior of individuals in political situations" [Sztompka 1975:80-81]. In terms of the methodological paradigm, it was, therefore, a kind of an empirical or positivist revolution in political science. 
The beginning of behaviorism in political science was marked by the well-known study by Lazarsfeld, Berelson and Gaudet entitled The People Choice [Ryszka 1984:354]. Its goal was to examine the relationship between voting decisions and the education, social and economic status, age and sex of the voters. Even though reception of this approach was not immediate, over the following decades the role of political studies focused on political behavior radically increased. They relied mostly on statistics and methods of social studies characteristic for sociology, and partially also for cultural anthropology. Consequently, the empirical method began to delineate the main (and still prevailing) research current in political science, with its multiple applications: starting from statistical analyses of "political activity, aimed at detecting patterns in voting behavior or relationships between such behavior and social background", through survey studies and opinion polls aimed at "identifying political views and standpoints", to laboratory experiments "which consist in simulating certain types of political relations, with the widest range of applications in the study of international relations" [Dubrzyńska 1998:19].

Almost from the very beginning, the empirical movement has been criticized as well, however. The triteness of its "allegedly scientific" conclusions was emphasized $^{1}$, as well as ignorance of vital social problems and overlooking "in the effort to be scientific and precise (...) moral and policy issues that make the discipline relevant to the real world"; finally, the fact that "many explanations and predictions in political science are weak or even false" [Johnson, Reynolds, Mycoff 2012:59,42]. In opposition to the empirical standpoint, a constructionist paradigm has emerged and grown in significance since the end of the 1970s. Its advocates claim that "humans do not simply discover knowledge of the real world through neutral processes, such as experimentation or unbiased observation; rather, they create the reality they analyze. In other words (...) what people often assume to be pure facts are conditioned by the observers' perceptions, experiences, opinions, and similar mental states" [Johnson, Reynolds, Mycoff 2012:57]. Consequently, scientific research (if this concept is still adequate, anyway $^{2}$ ) carried out within this current is focused around the problem of inter-

1 See e.g. the "spatial" theory of voting proposed by James Enelow and Melvin Hinch [1984], asserting that people support those parties and candidates who are closest to them; or the - otherwise valuable - work by Jurg Steiner [1997] who demonstrates that politicians sometimes follow their conscience in making political decisions. It appears that empirical studies often lead to a scientific "discovery" of obviousness.

2 Ultimately, constructionism seems to challenge the idea of objective epistemology or theory of knowledge [cf. Brzezińska, Gierycz, Burgoński 2018]. 
pretation, restoring normative reflection as an essential element in the study of politics. Methods derived from linguistic studies, such as critical analysis of discourse or interpretative analysis, have also been adapted, therefore, for use in political studies [cf. e.g. Yanow 1999].

Considering the fact that none of the traditions of viewing political studies briefly discussed above has been ultimately refuted by any other, it is important that we realize the accumulation of research methods employed in political science. And it should be stressed that these methods are derived from essentially disparate ways of understanding the goal of science itself. While the normative approach refers to classical reflection on politics related to philosophy, the empirical approach strives at providing political science with a scientific model characteristic of exact sciences [Cribb 1991:18].

This methodological heterogeneity of political science reveals a heterogeneity of all political knowledge. Henryk Przybylski suggests that in this context we should talk of source based and non-source based political knowledge. While the former "comes from a source, a reliable document, direct observation of a phenomenon, material trace of an activity, etc. which can be described as concrete and verifiable", the latter represents "an interiorized knowledge which ... by merging into all layers of our personality, speaks in us as 'the voice of conscience' when we evaluate a particular fact" [Przybylski 2004:19-20]. In other words, the empiricism and nomology of political science are not necessarily directly related. The identification of patterns and formulation of general laws about the political reality is not related in political science only to empirically investigated processes (even though - naturally - empirical observation always plays an essential role), but also to the operation of ideas, values, worldviews, and the entire "soft" sphere of our reflection on social life. This means that in the methodological specificity of political science there is, potentially, room for a political science of religion, since a political scientist must necessarily go beyond the instrumentation characteristic of the empiricism of social science ${ }^{3}$.

3 As a side remark, it is worth noting that this issue deserves some broader consideration in the context of the classification of political science in Poland as a discipline which belongs to social science. Taking into account the field of study proper to political science, its classification as social science seems to ignore its peculiar identity; it is an amputation of an essential part of its field of study. It would be much more legitimate to situate political science on the borderline between social science and the humanities. 
Considering the multiplicity of methods, corresponding to the multiplicity of issues related to the problems of government, political science runs the immanent risk of disciplinary decompression, so to say, or of remaining a collection of various scientific sub-disciplines "dealing with the investigation of political phenomena and processes by employing their own peculiar views and methods" [Kantyka 1999:199]. This threat is not purely theoretical. As David Easton has pointed out, in the 1950s in the United States it was difficult to justify the existence of a theory of politics as part of political science at all [Easton 1953:IX]. He indicated that the fact that "we can try to understand political life by viewing each of its aspects piecemeal" [Easton 1957:562] is methodologically problematic. Naturally, "we can examine the operation of such institutions as political parties, interest groups, government, and voting; we can study the nature and consequences of such political practices as manipulation, propaganda, and violence; we can seek to reveal the structure within which these practices occur. By combining the results we can obtain a rough picture of what happens in any self-contained political unit" [Easton 1957: 383]. Nevertheless, we cannot capture the whole this way, and "in combining these results ... there is already implicit the notion that each part of the larger political canvas does not stand alone but is related to each other part" [Easton 1957: 383].

If Easton actually wanted to "help in some small way to win back for theory its proper and necessary place" [Easton 1953:IX], he achieved much more. By suggesting that political life should be viewed as a system of interrelated activities, thus opening political analysis to the systemic paradigm (pluralist orientation), he in fact paved the way for an operationalization of the field of research in political science (pluralistic orientation), and ultimately its conversion into politology (monistic orientation). Consequently, systems analysis still remains "one of the most influential theoretical and methodological orientations in political analysis" [Chodubski 1999:28], making it possible to interpret not only various spheres of political life as "internally integrated wholes which are distinct from their environment and follow their proper rules", but also the relationship between political processes and other (cultural, economic, or social) phenomena.

When looking for a methodological approach, therefore, which would allow us to take religion into account when studying political phenomena, it seems necessary to begin by referring to this paradigm. For if we want to understand the influence of religion on the political process on many levels, and, for example, take into account the role of social awareness and common "pre-judgments" in 
the framework conditions of the political process, to understand the influence of religious institutions on the course of the political process, or the way religion is used by political actors, viewing politics as a process which occurs within a system appears to be very helpful.

\section{Around the System Approach}

It seems to be of key importance for us to understand the essence of a system approach. In political studies, it is sometimes treated as a theory, and at other times as a research technique. It does not appear to be either of the two, however.

As pointed out by Franciszek Ryszka, systems analysis is more a "methodological proposal rather than a complete theory" [Ryszka 1984:360]. The system here is a model or scheme which provides "a conceptual frame of reference within which the theory itself is to be built" [Krauz-Mozer 2005:58]. Therefore, as Barbara Krauz-Mozer suggests, „conceptual models represent a useful tool of research created at an initial stage in developing a theory, but may not be identified with it" [Krauz-Mozer 2005:58]. The employment of a systems perspective does not determine the form of the theory, therefore, but enables - by taking into account all essential elements and their interrelations - its construction. It delineates the area of legitimate searches and hypotheses.

The system approach is not a research method in the narrow sense of the word either. It should be considered as a methodological proposal in a broad sense: as a perspective highlighting elements of a system and the existence of relationships between them, which helps us observe a certain phenomenon. It does not, in itself, offer tools for investigating it, however. From this perspective, the methodological eclecticism of political science proves to be an advantage. From its diversified arsenal of research instruments, mostly borrowed from other humanistic and social studies, it may choose those techniques which are most useful in the investigation of an element or relationship perceived thanks to the systems perspective.

\subsection{An Outline of the Concept of David Easton}

The essence of the system approach - in Easton's view - is looking at political life as a system of interrelated activities, which determines the way they can be analyzed. Firstly, "the very idea of a system suggests that we can separate political life from the rest of social activity, at least for analytical purposes, and examine it as though for the moment it were a self-contained entity surrounded by, but clearly distinguishable from, the environment or setting in which it operates" [Easton 
1957:384]. The boundaries of this system are those activities which are directly related to the making of authoritative decisions, and the way in which it works is in part "a function of its response to the total social, biological, and physical environment" [Easton 1957:385].

Secondly, "if we hold the system of political actions as a unit before our mind's eye, as it were, we can see that what keeps the system going are inputs of various kinds. These inputs are converted by the processes of the system into outputs and these, in turn, have consequences both for the system and for the environment in which the system exists" [Easton 1957:384]. The outputs of the system are decisions made by the government, and the inputs are demands which require an organized effort on the part of the society, and support.

Both forms of inputs (demands and support) are of two different kinds. Demands may be external or internal. They may come from the environment (i.e. other systems: the economic, cultural, social, or demographic one), or from the inside. Internally inspired outputs, according to Easton, have more direct consequences than those coming from the outside 4 . Support, on the other hand, may consist either of actions "promoting the goals, interests, and actions of another person", or it may "involve not external observable acts, but those internal forms of behavior we call orientations or states of mind" [Easton 1957: 390]5. It each case, support refers to one of three objects: the political community, the regime, or the government.

Support is generated by inputs of the system (political decisions) which he believes to constitute "a body of specific inducements for the members of a system to support that system" [Easton 1957: 395], which are also of two kinds: positive and negative inducements, or rewards (satisfying some demands of its members), and sanctions6. In this sense, there is feedback between the inputs and the outputs of a system which ensures its balance, thus being a "vital mechanism in the life of a political system" [Easton 1957: 397]. Easton's formula is thus expressed in a model shown diagrammatically in the figure below:

4 As an example of such demands, Easton mentions "changes in the process of recruitment of formal political leaders, or modifications of the way in which constitutions are amended". [Easton 1975: 388-389]

5 Easton emphasizes here that "supportive states of mind are vital inputs for the operation and maintenance of a political system".

6 Easton also mentions a reserve of support, which is the support resulting from the conviction (mental state) that the government is generally favorable to the interests of its supporters, which allows it not to meet all of their demands. 


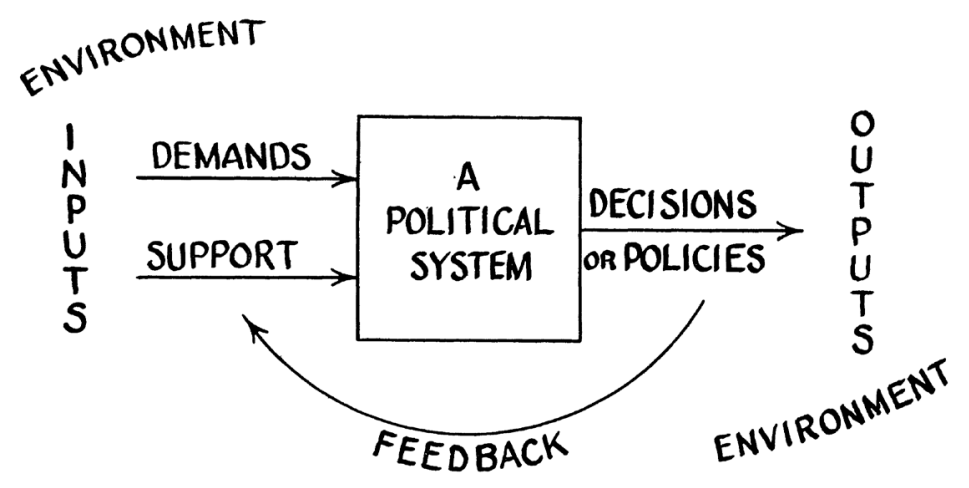

Fig. 2. David Easton's Model of a Political System

Source: Easton D., 1957, An Approach to the Analysis of Political Systems, in: World Politics, vol. 9, No.3, pp. 383-400.

\subsection{Contemporary Understanding of the System Approach in Political Science} The diagram presenting a systems analysis, even though created by David Easton himself, is imperfect as it does not take into account all internal demands (all seem to be inspired by the environment), and in fact it underestimates the process of politicization as a source of the system's stability, being an equivalent of the process of socialization in sociological analysis [Easton 1957: 574-575]. Moreover, it appears as though all support and demands were empirically measurable, while even the dual nature of the former makes it clear that they are not simply "observable". In this sense, the superficially model nature of the above diagram, suggestive of a positivist paradigm of scientificity, is somewhat misleading. To paraphrase Pierre Manent's opinion about Machiavelli, one might say, however, that in the case of an author of Easton's standing, it may be worthwhile taking a look at this superficiality, as it has influenced and is still influencing human minds.

It will not be an exaggeration to say that the understanding of systems analysis which results from the above diagram corresponds to the typical way in which it is viewed in political studies. It is assumed that "system inputs are supports originating in the environment (e.g. the payment of taxes, compliance) and demands (e.g. reduction of unemployment)" [Żebrowski 2012:30], and thus internal and external elements are integrated as system inputs. For example, in studies on the European Parliament, presented as an exemplary application of the system model in a major 
publication on the methodology of research in European studies, system inputs includ "the measures available to Polish Members of the Parliament", while bodies of the Parliament, the procedures and mechanism they employ were treated as the inside of the system [Szymański 2010:176]. This way Members of the Parliament who are undoubtedly part of the system of the European Parliament - were placed outside of it, as carriers of "inputs" into the system.

The above approach is justified to the extent that - as Anatol Rapoport pointed out - the system approach makes no restrictions as to the type of units which may represent 'elements' of a system. Neither does it make any restrictions as to the type of relationships which may exist between them. The only limitation is the requirement that both the elements and their relationships are unequivocally distinguishable [cf. Rapoport 1996:129]. Consequently, mezzo- and micro-level system analyses prevailing in political studies view the political system as the environment of the sub-system under investigation. This way, however, the research field of political science becomes narrowed down to its core. All that which is its actual environment, and which is therefore qualitatively different from the system itself, is no longer included in the researcher's perspective. This politological reduction results in an explicitly behavioral orientation of systems analysis. In contemporary political science, it is viewed as an approach which may be adequately "applied to the knowledge of so-called hard problems: institutions, social organization or structure, but is not convincing when applied to the study of "soft" problems: the system of beliefs, meanings, norms and rules, forms of discourse, collective mentality, etc.” [Chodubski 1999:28].

\subsection{Consequences of a Reductionist Understanding of Systems Analysis in Studying the Relationship Between Religion and Politics}

The understanding of the systems perspective briefly discussed above has significant consequences for the analysis of the relationship between religion and politics in contemporary political studies. Firstly, it results in religion being easily overlooked by political scientists. A small, but symptomatic example of this problem is provided by the way in which sources of the 1989/91 breakthrough and systemic transformation in Central and Eastern Europe were analyzed in political studies in Poland. Referring to the most important factors determining the genesis and development of the transformation in CEE, they list (even fifteen years after the transformation) various, certainly important, factors, such as: transformations in the USSR, the crisis of Eastern European economy, divisions within the Communist Party, the significance of non-confrontational groups within 
the opposition [Wonicki 2002], reforms carried out too late by the communists [Wiatr 2006], etc. What these analyses have in common is that they do not, in fact, consider religion worthy of note. In Polish literature on political studies, a thesis about the key role of religion in the processes of transformation was first defended by Edmund Wnuk-Lipiński in articles published in the „Chrześcijaństwo-ŚwiatPolityka" journal in 2007 [Wnuk-Lipiński 2007].

The narrowing down of the research field to a political sub-system in systems analysis also results in viewing religion solely as an institution (the Church, churches) so that it is impossible to distinguish it from other subjects of broadly understood political life. In consequence of this approach, the specific role of religion and religious institutions is negated. A good example of this process is the attitude to the role of churches in politics, visible in literature. Claims that from the theoretical perspective of the relationship between religion and politics, "it would be best if the Church actually functioned as one of the many institutions of the civic society, not having any privileged status compared to other (...) organizations" [Gdula 2010:73] are not isolated. On the other hand, there are also expectations that the Church should give up offering "certain content", for example about morality, and should concern itself instead "with particular forms and procedures of communal life and joint decision-making by the citizens" [Radwan 2015]. It seems that all such proposals result directly from narrowing down the analytic perspective to a political sub-system, and consequently from a reductionist approach to religion and religious institutions. From this point of view, as Bryan Wilson points out, there are ultimately no Churches, as the term should legitimately be used only in relation to "a monopoly of spiritual power on the coercive power of the political authority" [Wilson 2016:203].

The point is, however, that in fact Churches do exist, and their identity is not related to having at their disposal the coercive measures employed by political power. Moreover, their role in politics cannot be reduced to struggle for power (and much less to attending to their "own interests", which is characteristic of interest groups [Mazurkiewicz 2012:5-20]), and may therefore be completely unintelligible from the perspective of typical political analysis. If we look at the approach of John Paul II to the Eastern Bloc, we will notice that it begins with putting the classic view of politics, in this case international politics, "in parentheses". In his activities, almost from the very beginning of his pontificate, John Paul II challenged the foundations of the most reasonable - from the point of view of 
political calculations - Ostpolitik of Cardinal Casaroli [Weigel 1995:129-133]. He did not acknowledge geopoligical necessities, so to say; instead, he took "seriously" the framework of doing politics in Poland, whose identity had been related from the very beginning to Catholicism. Consequently, he in fact negated the idea of the Eastern politics of "small steps". The papal mission almost at the very start put politics "in parentheses", while at the same time leading the framework in which it was done out of the shadows. The Pope's offensive, so to say, was evangelical: it was based on proclaiming the truth about God and man inherent to the Christian message, together with the historical truth about Poland whose past was inseparably related to Christianity. Its addressees were not states or institutions, but individuals and societies. It was them the Pope addressed as their pastor, often ignoring the accepted political custom. And it was this non-political involvement that was of fundamental political significance, and not the political negotiations with Wojciech Jaruzelski, or the exchange of views with Henryk Jabłoński.

Summing up, the empirical and functional approach to the systems method prevailing in political science, while being legitimate, does not capture the complexity of political processes, particularly with regard to the role played in these processes by religion. This is due to the fact that it always remains, so to say, on the "surface" of the observed phenomena. In this context, Robert Esposito points to the deficit of depth and substance in the language of political science [Esposito 2015:67]. It hinders a proper understanding of the observed phenomena, particularly in the case of the role of the religious factor we are interested in here . $^{8}$ A political system is more than just the issue of $a d$ hoc majority and its demands or support. Both the form of the system and its inputs and outputs are much more deeply rooted in the ways of thinking and understanding the world prevailing in a given culture, including the key aspect of "pre-judgments" about what is right and what is wrong; about the ultimate goal and meaning of life; and, finally, about whether God exists or not.

\section{Towards a „In-depth Systems Analysis”}

The question is whether we are doomed to such a model of understanding systems analysis. It might appear that the empirical and functional understanding of the

Whose acceptance may be linked to taking the edge off the Church's criticism of communism during the pontificates of John XXIII and Paul VI [cf. Weigel 1995: 132-133].

8 Simone Weil actually claimed that we can take almost every expression or term in our political dictionary, and when we look inside, we will find that it is empty [cf. Weil 2004: 424]. 
systemic method is fully compatible with the methodological orientation of David Easton himself, who may be considered a representative of the empirical revolution in political science. Nevertheless, the situation is not as obvious as it might appear. It is true that - from the vantage point of Eastonian research - a broadly understood behavioral perspective is fully substantiated. Still, Easton's theory also has a great potential - which seems to have not been fully taken advantage of - of carrying out an in-depth analysis of politics, which I suggest we call in-depth systems analysis.

\subsection{Religion and Culture in Systems Analysis}

In the above context, we may want to consider the approach to culture and religion in the area of politics presented by David Easton. He pointed out that "the members of every society act within the framework of an ongoing culture that shapes their general goals, specific objectives, and the procedures that the members feel ought to be used" [Easton 1957:390]. He emphasized that "the typical demands that will find their way into the political process will concern the matters in conflict that are labeled important by the culture. For this reason we cannot hope to understand the nature of the demands presenting themselves for political settlement unless we are ready to explore systematically and intensively their connection with the culture" [Easton 1957: 567]. This reflection points to not only the possibility, but in fact to the indispensability of an in-depth analysis if the system model is to be applied properly. Furthermore, analyzing the process of politicization - not represented in the above diagram - as an important factor consolidating the political system, the author of The Political System underlined the fact that "the various political myths, doctrines, and philosophies transmit to each generation a particular interpretation of the goals and norms" [Easton 1957: 399], creating the foundations determining the proper or expected behavior in specific political situations.

The above observation - let us make it clear - is not some kind of a research directive detached from the systems approach, and added for no apparent reason to reflections on the political system. On the contrary, it is consistent with the entire logic of systemic thinking in social science, which assumes that "the regularity or patterning of interaction becomes possible through the existence of norms which control the behavior of the actors. (...) Indeed, a stabilized social system is one in which behavior is regulated in this way and, as such, is a major point of reference for the sociological analysis of the dynamics of social systems" [Lockwood, 1956:135]. Social order is possible thanks to a normative order, which - even 
recognizing the legitimacy of Lockwood's criticism of Parsons ${ }^{9}-$ unless it is the only variable, represents, together with the social stratum, one of the two key ones. Easton was fully aware of this. He emphasized that „it is essential for the viability of an orderly political system that the members of the system have some common basic expectations with regard to the standards that are to be used in making political evaluations, to the way people will feel about various political matters, and to the way members of the system will perceive and interpret political phenomena” [Easton 1957: 398].

Once we realize the meaning of normative standards, we are able to ask the questions we are interested in concerning the political science of religion. The accepted norms, among which "the most important are moral standards" [Lockwood 1956:135], ultimately lead to taking the significance of religion, together with its related anthropological or eschatological beliefs, for the political process into account in political analysis. In this sense, systems analysis requires depth - to uncover the sources and possible trajectories of political thought and action, the framework conditions of such action, so to say, thus outlining the space for a political science of religion.

At the same time, one must admit that in Easton's model itself the issue of taking normative standards into account has not been operationalized, and remains more a theoretical directive than an instrument of research praxis. In other words, while the systemic model theoretically makes it possible to take the theoretically recognized role of religion, and the culture for which it provides foundations, seriously as an environment exerting fundamental influence on the functioning of the system, and thus appears to be a useful paradigm for a non-reductionist political science of religion; in the practice of political studies - as has been demonstrated above - the environment and its role are considerably restricted by a "politological reduction": focusing on intra-systemic inputs, or applying the systems model to micro- and mezzo-level systems analyses, where the problem under investigation is but a fragment of a broader political system, thus becoming the environment for the studied political sub-system.

Not aspiring to solve the problem of adding depth to the systems method in a brief article, I would like to point to some clues which may be useful in this context,

9 Talcott Parsons distinguished between three subsystems of the environment, resulting from the functional approach: the economic and technological one (the function of adaptation); the family one (the function of upholding models); culture, religion, art (the function of integration) [Sztompka 1975:96]. 
however. These clues, let me add, refer to the issue which political science - or so it seems to me - has had the most trouble with, namely that of taking religion seriously as an essential element exerting influence on the framework conditions of a political process. Naturally, these remarks also pave the way for developing an appropriate approach to institutional religious actors, even though - due to the already excessive length of this article - I will not discuss this issue here.

\subsection{The Environment and the System - "Time Difference"}

The above-mentioned "politological reduction" of the role of the environment (including religion) which does not fully yield to social studies comes as no surprise. The problem with the operationalization of taking the significance of religion as the context in which politics happens into account within the framework of systems analysis seems to arise from the temporal incompatibility of the cultural and political context. In relation to the theoretical work of Fernand Braudel, we may notice that there are ,at least three planes. One, which we may call $\mathrm{A}$, is that of traditional history, habitual narrative, hurrying from one event to the next like a chronicler of old or a reporter of today (...). A second plane - B - is that of episodes, each taken as a whole: Romanticism, the French Revolution, the Industrial Revolution (...). They can be regarded as events of long duration, stripped of superfluous detail. A third plane - C - transcends these events: it considers only phenomena that can be measured over a century or more. (...) On this last level (...) civilizations (...) reveal their longevity, their permanent features, their structures - their almost abstract but yet essential diagrammatic form" [Braudel 1995:68]. The model of systems analysis prevailing in political science is concerned with the short-term: that of political processes happening "right now", the so-called events history. The cultural context of key importance - according to Easton himself - for understanding these processes is the dimension of long-term, even great-term duration, revealing fundamental structures and thinking patterns delineating its trajectories in the short time.

As we perceive this "time difference", we discover a research directive of essential importance for analyzing religion and politics. Namely, in-depth systems analysis should strive towards uncovering the relationship between two levels of time: political events studied in the short-time perspective, and transformations in ideas and ways of thinking which determine the standards of value-judgments and norms defining the structures of institutional operation. In this perspective, analysis of political processes should take into account the fact that ,the conscious policies of men and governments are (...) deductions from our most basic ideas of 
human destiny, and they have a great, though not unobstructed, power to determine our course" [Weaver 1984:3].

A research tradition which seems to be useful in this process is hermeneutics, or, to be more precise, the hermeneutically-oriented phenomenology $y^{10}$. Hermeneutics, as has been pointed out by Wilhelm Dilthey, is a theory of the art of understanding manifestations of life as they are recorded in writing. This knowledge is achieved through construction, i.e. interpretation [Gadacz 2009:130]. This is a manifest expression of the aftermath of the exegetic tradition. Since "life is a text" which is open to interpretation [Bollonow 1994:17], the starting point here is the specific political phenomenon which - in accordance with the logic of the hermeneutic circle - is subject to ever deepening analysis in the context of the entire cultural tradition. This way, thanks to the hermeneutic circle, "the time distance from the cultural achievements of the past is no longer an obstacle to understanding" [portal 2017]. On the contrary, it allows for placing the observed phenomena against a broader cultural context.

A good exemplification of such hermeneutics may be the perception of the phenomenon of limited power, essential for modern democracies, in the specific context of the Western culture. As has been pointed out by Leszek Kołakowski, the Promethean paradigm of revolution rejects "the idea of original sin understood so that it requires an external redemptive intervention" [Kołakowski 2006:311]. By contrast, the ultimate reason for institutional limitation of power, e.g. in the form of a tripartite separation, is anthropological in nature. What does it mean, however? As has been stressed by many scholars [cf. eg. Delsol 2016, Mazurkiewicz 2017, Gierycz 2017], a realistic anthropology makes it mandatory to respect the equal and inviolable dignity of every person, the natural human inclination towards good, and the universal tendency to choose evil. When trying to understand these claims, it is necessary to discover their theological sources. The first element is related to the Biblical belief in the creation of man "in the image and likeness" of God, which makes man the subject of certain inherent and inviolable rights. The two latter - to belief in the original sin which has "damaged", but not entirely destroyed the orientation of human nature towards good.

10 To cite Helmuth Plessner, we may say that this is - generally speaking - about understanding seen as insight into objects which, expressing themselves, give witness about themselves; understanding which begins with the sensual and visual layer and penetrates down to the essential core, being at every stage a unity of direct witness and intellection [cf. Plessner 2018:37]. 


\subsection{Inputs and the Inside of the System - „Transmission Channels” and „Borrowings"}

Another path, different from the hermeneutic tradition, to uncovering the significance of religion for the framework conditions of a political process is a method developed, for example, by Ernst Kantorowicz and Carl Schmitt.

In his well-known treatise, Ernst Kantorowicz discusses the formula of "the king's two bodies" which had been upheld in England for many long centuries. It played a considerable role in the history of England during the trial of Charles Stuart, when "only" his natural body was executed "without affecting seriously or doing irreparable harm to the King's body politic" [Kantorowicz 1997:23]. How could the king be executed without his body being destroyed? English lawyers of the $16^{\text {th }}$ century claimed that "the King has in him two bodies, viz., a Body natural, and a Body politic. His Body natural (if it be considered in itself) is a Body mortal, subject to all Infirmities that come by Nature or Accident (...). But his Body politic is a Body that cannot be seen or handled, consisting of Policy and Government, and constituted for the direction of the people, and the Management of the public weal, and this Body is utterly void of (...) natural Defects and Imbecilities" [Kantorowicz 1997:7]. Without going into the detailed definitions of the King's two bodies, which the English doctrine had done an admirable job in developing ${ }^{11}$, Kantorowicz points out that the speculations of English jurists concerning fundamental political institutions are crypto-theological. He asserts that "we need only replace the strange image of the Two Bodies by the more customary theological term of the Two Natures in order to make it poignantly felt that the speech of the Elizabethan lawyers derived its tenor in the last analysis from theological diction (...) [transferring the theological doctrine] to the sphere of the state the head of which is the king" [Kantorowicz 1997:16].

A strikingly similar observation has been made by Carl Schmitt about the national state. In his Political Theology he argues that „all significant concepts of the modern theory of the state are secularized theological concepts" [Schmitt 1985:37]. The way he understood it, conceptual analogy meant that meanings assigned to a particular legal concept in the political community reflect a corresponding theological concept in their structure and content. Schmitt demonstrates this using the example of the idea of state. He proves that the concept of state

11 At one point in his reflections, Kantorowicz examines the „Creed of Royalty” in the context of its „orthodoxy”. The doctrine of the King's Two Bodies passes the test with flying colors, the only possible danger being that of Monotheletism. Cf. Kantorowicz 1997: 17-18. 
secularizes the idea of almighty God, reflecting his omnipotence, omnipresence, his unity of nature in the multiplicity of persons, and even his mercy. He points out that "the state intervenes everywhere. At times it does so as a deus ex machina, to decide according to positive statute a controversy [...]; at other times it does so as the graceful and merciful lord who proves by pardons and amnesties his supremacy over his own laws. There always exists the same inexplicable identity: lawgiver, executive power, police, pardoner, welfare institution" [Schmitt 1985:38]. Consequently, the meanings contained in the concept of God and the very structure of this concept have evident analogies in the concept of state [Schmitt 1985:40]. Schmitt, like Kantorowicz, notes the crypto-theological language of the science of the state. In addition, by pointing out conceptual analogies, he claims that concepts of key importance for the political construct have been borrowed from the sphere of religion.

It should be added that neither Kantorowicz nor Schmitt limit their analyses of borrowings to diagnosing an analogy between concepts or their contents. Both of them look for possible channels of transmission; neither accepts any oversimplified solutions in this matter. For example, while Kantorowicz asserts that "the cryptotheological idiom was not the personal spleen of any single one among the Tudor lawyers, nor was it restricted to a small coterie of judges" [Kantorowicz 1997:19], and that quite on the contrary, it was a common and widespread phenomenon, he also stresses that one should not conclude that "the lawyers consciously borrowed from the acts of the early Councils" [Kantorowicz 1997:18]. Similarly, while Schmitt notices the above-mentioned analogy between concepts, he emphasizes that it is not a matter of simple reproduction. At one point, he explicitly writes that he does not believe it to be a good example of political theology to argue that ,the monarchy of the seventeenth century is characterized as the real that is 'mirrored' in the Carthesian concept of God" [Schmitt 1985:45].

Schmitt suggests another explanation of the borrowing. He agrees that "the historical-political status of the monarchy (...) is shown to correspond to the general state of consciousness that was characteristic of western Europeans at that time" [Schmitt 1985:45-46], and that the legal form of this historical and political reality was expressed in a concept whose structure coincided with the structure of metaphysical concepts. He believes, therefore, that religious concepts appear in the legal system of a state indirectly through the political concepts of its community. Theological analogies appear due to the fact that political concepts are founded on a particular religious awareness - being the most profound basis for 
the structure of political concepts as they are being developed. Religious content is therefore not used directly, but indirectly. Secularization of religious concepts is related to their content being expressed in political categories, which results from a particular shape of social awareness. For Schmitt, who asserts that the state emerges as a result of religious wars, i.e. in the moment when the supreme ideas forming the social perception of the world are of a religious nature, this explanation exhausted the matter.

The analyses performed by Kantorowicz, who clearly does not contradict Schmitt's belief in the indirectness of the borrowing process, draws our attention to yet another element in the process of transmitting concepts and meanings from religion to politics. Kantorowicz emphasizes, in the context of the problem he analyzes, that one cannot "preclude the possibility that corporational and other concepts defining the papal power were directly transferred and purposely introduced into Tudor England to bolster the royal power" [Kantorowicz 1997:19]. This way Kantorowicz points out that the transmission of religious concepts may proceed almost "directly". Not in the sense that a particular concept is transferred directly from theology; what he means is rather that this may be the case of politics using concepts which have become secularized, or partially secularized, within the Church itself. Kantorowicz describes this process in detail using the example of the concept of corpus misticum which, as we will recall, English jurists had borrowed to describe the royal body ${ }^{12}$. In the process of borrowing, an important role is thus played both by religious and by political actors.

The above analyses show that political science is capable of calibrating its research tools, both at the level of paradigms (the systems perspective), and specific techniques (analysis of borrowings, hermeneutics), so that a non-reductive approach can be developed to the phenomenon of religion and its role in the political process. Objectively speaking, it is not necessary, therefore, to force political

12 Kantorowicz points out that the concept of corpus misticum, initially meaning the Eucharist - the consecrated Host - became gradually transposed to the community of the Church, and subsequently - always within the Church itself - turned into a "legal abstract", a "mystical person", a concept which is similar, if not synonymous, to that of "fictitious person" which the jurists introduced into the legal thought, and which can be found in the foundations of many political theories of the Middle Ages. The observation made by Kantorowicz reveals, therefore, that also the Church may make an essential contribution to the process of borrowing concepts. Not so much in the sense of creating them (which, naturally, is also the case), but of their initial secularization which facilitates their "interception" by the secular sphere. 
studies of religion into a rigid methodological straightjacket tailored in the spirit of Vilfrido Pareto, or to adopt an approach which negates the specific nature of religion compared to other phenomena in broadly understood political life. At times, as in the case of systems analysis, it is enough to take full advantage of the potential inherent to the concept of political science. In this sense, the road of a political science of religion seems possible, and may be an essential contribution to the identity of politology. The only problem is that - as is otherwise seen in positive terms - "tradition obliges". In this case, the atheistic tradition of political science mentioned by Boeckenfoerde needs some controversy in order to leave the question about God open, and thus take answers to this question seriously.

\section{Bibliography}

Antoszewski A. (1975), Politologia, in: A. Antoszewski, R. Herbut [ed.], Leksykon politologii, atla 2, Wrocław 2004.

Böckenförde E. W. (2005), Teoria polityki a teologia polityczna. Uwagi na temat ich wzajemnego stosunku, “Teologia polityczna” No. 3.

Bollonow O. F. (1994), Wilhelm Dilthey jako twórca filozofii hermeneutycznej, trans.

E. Paczkowska-Łagowska, "Studia z Filozofii Niemieckiej" vol. 1, p. 17; as quoted in:

T. Gadacz, Historia filozofii...

Braudel F. (1995), A History of Civilisations, Penguin Books, New York.

Brzezińska M., Gierycz M., Burgoński P. (2018), Analiza dyskursu politycznego. Teoria, zastosowanie, granice naukowości, Wydawnictwo Naukowe UKSW, Warszawa.

Burgoński P., Gierycz M. (2014), Religia i polityka. Zarys problematyki, Elipsa, Warszawa.

Chodubski A. (1999), Analiza polityczna, in: W. Sokól, M. Żmigrodzki [ed.], Encyklopedia politologii, vol. 1: Teorie polityki, Zakamycze, Kraków.

Cribb A. (1991), Values and Comparative Politics. An introduction to the philosophy of political science, Avebury, Adershot.

Delsol Ch. (2017), Nienawiść do świata. Ponowoczesność i totalitaryzmy, PAX, Warszawa

Dubrzyńska H. (1998), Elementy teorii polityki, Uniwersytet Gdański, Gdańsk.

Dylus A. (2014), "Krytyka 'zabójczej' gospodarki. Ujęcia Evangelii Gaudium”, Chrześcijaństwo - Świat - Polityka No. 15/16.

Dylus A. (2016), Polityka w perspektywie etycznej i religijnej, Wyd. UKSW, Warszawa.

Easton D. (1953), The Political System. An Inquiry Into A State Of The Political Science, H. Wolff, New York.

Easton D. (1957), An Approach to the Analysis of Political Systems, in: World Politics, vol. 9, No.3, pp. 383-400.

Enelow J., Hincha M. (1984), The Spatial Theory of Voting: An Introduction, Cambridge University Press, New York. 
Esposito R. (2015), Pojęcia polityczne. Wspólnota, Immunizacja, Biopolityka, trans. Katrzyna Burzyk et al., Universitas, Kraków.

Gadacz T. (2009), Historia filozofii XX wieku. Nurty, vol. 1, Znak, Kraków.

Gdula M. (2010), Kohabitacja i sojusz. Polityka i Kościół w Polsce 1945 - 2009, in: Kościót, państwo i polityka płci, H. Boell Stiftung, Warszawa.

Gierycz M. (2008), Chrześcijaństwo i Unia Europejska. Rola religii w procesie integracji europejskiej, WAM, Instytut Politologii UKSW, Kraków - Warszawa.

Gierycz M. (2017), Europejski spór o człowieka. Studium z antropologii politycznej, Wyd. Naukowe UKSW, Warszawa.

Haynes J. (2009), Routledge Handbook of Religion and Politics, Routledge, London \& New York.

Johnson J. B., Reynolds H. T., Mycoff J. D. (2012), Political Science Research Methods, CQ Press, Thousand Oaks, California.

Kantorowicz E. (1997), The King's Two Bodies. A Study in Mediaeval Political Theology, Princeton University Press, Princeton.

Kantyka Z. (1999), “Nauki polityczne”, in: W. Sokół, M. Żmigrodzki [ed.], Encyklopedia politologii, vol.1: Teorie polityki, Zakamycze, Kraków.

Kołakowski L. (2006), “O duchu rewolucyjnym”, in: Tenże, Czy diabeł może być zbawiony i 27 innych kazań, Znak, Kraków.

Koło hermeneutyczne, paneef2.republikapl/hasla/h/hermeneutyczne.html.

Krauz-Mozer B. (2005), Teorie polityki, PWN, Warszawa.

Lockwood, D. (1956), "Some Remarks on The Social System”, The British Journal of Sociology, 7 (2).

Longman T. (2001), "Church Politics and the Genocide in Rwanda", Journal of Religion in Africa, Vol. 31, Fasc. 2, Religion and War in the 1990s.

Marczewska-Rytko M. (2010), Religia i polityka w globalizującym się świecie, Wyd. UMCS, Lublin.

Mazurkiewicz P. (2012), Niepolityczna polityczność Kościoła, „Chrześcijaństwo - Świat - Polityka” No 13 (1).

Mazurkiewicz P. (2017), Europa jako kinderniespodzianka, OMP, Kraków.

Michalak R. (2016), Implementacja zasad religijnych w sferze politycznej, Morpho, Zielona Góra.

Plessner H. (2018), Political Anthropology. Studies in Phenomenology and Existential Philosophy, Northwestern University Press, Evanston, Illinois.

Przybylski H. (2004), Politologia. Zarys problematyki, Wyd. Naukowe Śląsk, Katowice - Warszawa.

Radwan A. (2015), Kościele, proszę nie milcz!, „Rzeczpospolita”, http://www.rp.pl/ Publicystyka/312309838-Kosciele-prosze-nie-milcz.html\#ap-1.

Rapoport A. (1966), Some System Approaches to Political Theory, in: D. Easton [ed.], Varieties of Political Theory, Prentice-Hall, Englewood Cliffs.

Ryszka F. (1984), Nauka o polityce. Rozważania metodologiczne, Warszawa.

Schmitt C. (1985), Political Theology. Four Chapters on the Concept of Sovereignty, University of Chicago Press, Chicago.

Schwaabe Ch. (2010), Politische Theorie 1. Von Platon bis Locke, 2., durchgesehende Auflage, Wilhelm Fink, Paderborn. 
Sobolewski M. (1975), Historyczne ujęcie zjawisk politycznych, in: K. Opałek [ed.], Metodologiczne i teoretyczne problemy nauk politycznych, PWN, Warszawa.

Steiner J. (1997), Sumienie w polityce. Empiryczne badania przypadków trafności decyzji politycznych w Szwajcarii, trans. J. Sowa, JanSowa, Wyd WSP, Rzeszów.

Sulkowski M. (2018), "Ideologia Państwa Islamskiego”, Chrześcijaństwo - Świat - Polityka No.22.

Sztompka P. (1975), “Analiza systemowa w naukach politycznych. Próba rekonstrukcji”, in: Kazimierz Opałek [ed.], Metodologiczne i teoretyczne problemy nauk politycznych, PWN, Warszawa.

Szymański A. (2010), “Systemowe podejście w badaniach europejskich”, in: W. Jakubowski, K. A. Wojtaszczyk [ed.], Studia europejskie. Zagadnienia metodologiczne, WAiP, Warszawa.

Weaver R. M. (1984), Ideas Have Consequences, University of Chicago Press, Chicago and London.

Weigel G. (1995), Ostateczna rewolucja. Kościót sprzeciwu a upadek komunizmu, W drodze, Poznań.

Weil S. (2004), "Nie rozpoczynajmy znowu wojny trojańskiej”, in: id., Dzieła, trans. M. Frankiewicz, Brama. Książnica Włóczęgów i Uczonych, Poznań.

Wiatr J.J. (2006), Europa pokomunistyczna, Scholar, Warszawa.

Wilson B.R. (2016), Religion in Secular Society: Fifty Years On, Oxford University Press

Wnuk-Lipiński E. (2007), "Meandry kształtowania się społeczeństwa obywatelskiego w Europie Środkowo-Wschodniej”, Chrześcijaństwo - Świat - Polityka 2007 No.2 (1).

Woleński J., "Spór o status metodologiczny nauk o polityce”, in: K. Opałek [ed.], Metodologiczne i teoretyczne problemy nauk politycznych, PWN, Warszawa.

Wonicki J. (2002), Trudna droga do demokracji. Europa Środkowo-Wschodnia po 1989 roku, Warszawa.

Yanow D. (1999), Conducting interpretive policy analysis, Sage Publications, Thousand Oaks, London, New Dehli.

Żebrowski W. (2012), Badanie polityki. Ogniwa procesu badawczego na studiach politologicznych, INP UWM, Olsztyn. 